\title{
Behaviour, tolerance and anaerobic metabolism under hypoxia in the brackish-water shrimp Crangon crangon
}

\author{
Lars Hagerman $^{1} \&$ Anna Szaniawska $^{2}$ \\ ' Marine Biological Laboratory, Strandpromenaden, DK-3000 Helsingor, Denmark \\ ${ }^{2}$ Instytut Oceanografii, Uniwersytet Gdañsi, Al. Czolgistów 46, 81-378 Gdynia, Poland
}

\begin{abstract}
Behavioural and metabolic reactions of Crangon crangon $\mathrm{L}$. were studied at different activity levels in shrimp exposed to various degrees of hypoxia. At $20^{\circ} \mathrm{C}$, the normally buried $\mathrm{C}$. crangon emerges from the sand at a $\mathrm{P}_{\mathrm{w}} \mathrm{O}_{2}$ of 40 to $50 \%$ saturation $(20 \% \mathrm{~S})$; at $9^{\circ} \mathrm{C}$, the emersion response occurs at $\mathrm{P}_{\mathrm{w}} \mathrm{O}_{2} 20 \%$. A swimming reaction was always noted at $\mathrm{P}_{w} \mathrm{O}_{2} 30$ to $40 \%(20 \% \mathrm{~S}$; $20^{\circ} \mathrm{C}$ ). Regardless of salinity, survival was high down to $\mathrm{P}_{w} \mathrm{O}_{2} 30 \%$. LT $\mathrm{LT}_{50}$ was strongly dependent on $\mathrm{P}_{\mathrm{w}} \mathrm{O}_{2}$ and salinity; thus at $10 \% \mathrm{~S}, \mathrm{P}_{\mathrm{w}} \mathrm{O}_{2} 10 \%: \mathrm{LT}_{50}=4.5 \mathrm{~h}$; at $20 \% \mathrm{~S}, \mathrm{P}_{\mathrm{w}} \mathrm{O}_{2} 10 \%: \mathrm{LT}_{50}=6 \mathrm{~h}$; at $10 \%$ $\mathrm{S}, \mathrm{P}_{\mathrm{w}} \mathrm{O}_{2} 20 \%: \mathrm{LT}_{50}=>150 \mathrm{~h}$. Circulating lactate was accumulated only at $\mathrm{P}_{\mathrm{w}} \mathrm{O}_{2} 10 \%$ saturation or lower. Normoxic lactate levels were ca $10 \mathrm{mg} 100 \mathrm{ml}^{-1}$ and increased in $\mathrm{P}_{\mathrm{w}} \mathrm{O}_{2}$ less than $10 \%$ to 80 to $100 \mathrm{mg} 100 \mathrm{ml}^{-1}$ after 3 to $4 \mathrm{~h}$. C. crangon will die quickly at this $\mathrm{P}_{\mathrm{w}} \mathrm{O}_{2}$, unless higher oxygen tensions prevail rapidly. Return to normoxic conditions caused circulating lactate to be re-oxidised to normoxic levels within 5 to $6 \mathrm{~h}$. When $\mathrm{C}$. crangon was forced to swim in different $\mathrm{P}_{\mathrm{w}} \mathrm{O}_{2}$ for up to $2 \mathrm{~h}$ the circulating lactate remained, regardless of the $\mathrm{P}_{\mathrm{w}} \mathrm{O}_{2}(100$ to $40 \%$ sat.) at normoxic levels. Oxygen consumption $\left(\mathrm{MO}_{2}\right.$ ) rose to varying degrees $\left(5\right.$ to $70 \%$ of routine $\mathrm{MO}_{2}$ ) when $C$. crangon was forced to swim for $2 \mathrm{~h}$. No sign of oxygen debt was found after a swimming period. Due to a higher $\mathrm{MO}_{2}$ when exposed to $\mathrm{P}_{w} \mathrm{O}_{2}$ of 40 to $50 \%$, swimming $\mathrm{MO}_{2}$ under these conditions rose only 10 to $15 \%$. During escape reactions $C$. crangon used its abdominal muscle, but after ca 15 contractions that muscle showed signs of fatigue. No increase in circulating lactate was found after such escape reactions. $\mathrm{MO}_{2}$ under escape reactions increased up to $211 \%$ of routine $\mathrm{MO}_{2}$ at normoxic $\mathrm{P}_{\mathrm{w}} \mathrm{O}_{2}$. Here also the $\mathrm{MO}_{2}$ returned quickly to routine levels without any signs of oxygen debt.
\end{abstract}

\section{INTRODUCTION}

Hypoxia is widespread, and its frequency is reported to increase in shallow waters, mainly due to increased eutrophication (e.g. Miljøstyrelsen 1984). For motile animals it is reasonable to propose that a primary reaction to severe hypoxic conditions would be an attempt to move away (escape reaction). If this is not possible, or if the hypoxia is not severe enough to evoke an escape response, then even at moderate hypoxia, oxygen transport into the animal may be impaired and thus its respiratory physiology affected.

The brackish water shrimp Crangon crangon L. initially compensates for decreased oxygen availability in the environment by an increase in ventilation, a normal reaction among decapods (McMahon \& Wilkens 1983). It thus manages to maintain its respiratory rate $\left(\mathrm{MO}_{2}\right)$ at a stable level down to a certain critical $\mathrm{O}_{2}-$ tension $\left(\mathrm{P}_{c}\right)$ (Hagerman \& Szaniawska unpubl.). At still lower oxygen tensions in the water $\left(\mathrm{P}_{\mathrm{w}} \mathrm{O}_{2}\right)$, the shrimp sooner or later suffers from oxygen deficiency in its tissues, resulting in lactate accumulation (anaerobic metabolism). Lactate is one of the end products of anaerobic metabolism in crustaceans (e.g. Bridges \& Brand 1980). Both the oxygen tension at which this anaerobic metabolism starts and the ability to reoxidise the lactate quickly depend on environmental factors and the physiological condition of the individual concerned.

In most respiration studies routine $\mathrm{MO}_{2}$ is measured and only limited knowledge exists on the metabolic cost of swimming. Published values vary 3 to 10 -fold over the resting $\mathrm{MO}_{2}$, depending on the degree of activity, behaviour and ecological niche (e.g. Booth et al. 1982). Pleopod swimming constitutes a normal behaviour in Crangon crangon (e.g. Hagerman 1970) 
and hence could be supposed to increase the routine $\mathrm{MO}_{2}$ only to a moderate degree. On the other hand, violent activity outbursts during escape reactions, i.e. when the shrimp uses its powerful abdominal muscle, could be expected to increase rapidly the $\mathrm{MO}_{2}$ and to lead to fatigue within a short time due to the high amounts of energy needed.

The purpose of this investigation is to study the behavioural and metabolic reactions of Crangon crangon, at different activity levels, to various degrees of hypoxia.

\section{MATERIALS AND METHODS}

Crangon crangon were collected by a man-powered minitrawl in the Roskilde-Isefjord (Denmark) at a water depth of 0.5 to $1.5 \mathrm{~m}$ during late summer/early autumn $1985\left(20^{\circ} \mathrm{C} ; 20 \%\right.$ S). Upon return to the laboratory Crangon crangon was stored in running seawater $(20 \% \mathrm{~S})$ for at least $1 \mathrm{wk}$ before experimentation. All storage aquaria had a sand substrate. The shrimps were fed (bivalves, mysids, worms or other shrimp), but received no food during respiration experiments.

For behaviour and tolerance experiments at least 20 shrimp were used per salinity/oxygen combination

Survival was tested by keeping Crangon crangon at $20^{\circ} \mathrm{C}$ (summer temperature) in combinations with different $\mathrm{P}_{\mathrm{w}} \mathrm{O}_{2}(5,10,20,30 \%$ saturation) and salinities $(5,10,20 \%$ S), i.e. under conditions that local populations might encounter (Muus 1967). After $3 \mathrm{~h}$, mortality was recorded every $10 \mathrm{~min}$ and once per hour; after $12 \mathrm{~h}$, mortality was recorded daily. Oxygen tensions in the water were decreased by bubbling with $\mathrm{N}_{2}$ and monitored either via a Radiometer oxygen electrode E 5047 connected to an acid-base analyser PHM 71 or via a YSI model 58 oxygen meter.

Blood samples from Crangon crangon were taken in 30 min or shorter intervals from the heart region by carefully inserting a hypodermic needle, collecting 5 to $100 \mu$ haemolymph depending on body size. Each shrimp was sampled only once. Haemolymph lactate was determined using Boehringer Test Combination no. 124842. Absorbance was read against the reagent blank at $340 \mathrm{~nm}$ using a Unicam SP 1800 UV-spectrophotometer. L-lactate concentration was calculated according to the values provided in the test combination table. These values were checked using an Llactate calibration standard. Graham et al. (1983) suggested that the end point of the reaction for lactate analysis is unstable due to interferences from the $\mathrm{Cu}^{++}$ ions liberated into the sample when the haemocyanin in the preparation procedure is precipitated by perchloric acid. Lowering of the $\mathrm{pH}$ of the glycine/hydracine buffer (Sigma Chemical Co) from 9.2 to 9 with
$\mathrm{HCl}$ and $12 \mathrm{mM}$ EDTA completely eliminates this interference (Engel \& Jones 1978) and produces a stable end point. However the Boehringer Test Set has a glycine/hydracine buffer with a $\mathrm{pH}$ of 9.0 and stable end points have been obtained without the use of EDTA (see also Johnson 1985).

Oxygen consumption rates $\left(\mathrm{MO}_{2}\right)$ were measured in a flow-through system where oxygen tension of thermostatted water entering and leaving the respiration chamber was monitored continuously by 2 Radiometer E 5047 electrodes connected to 2 acid-base PHM 71 analysers and a Goerz Servogor 220 recorder. Water was pumped via a Cole-Palmer peristaltic pump and tygon tubing was used. The flow rate was adjusted to give a $\mathrm{MO}_{2}$ of around $15 \%$ of the available oxygen, normally this meant a flow of 1.2 to $3.2 \mathrm{ml} \mathrm{min}^{-1}$. depending on the size of the shrimp. The respiration chamber was $8 \mathrm{~cm}$ long and $2.5 \mathrm{~cm}$ in diameter (internal measurements). A thin layer of sand was used as substrate in the respiration chamber (unless otherwise stated). The sand was changed before each experiment. Blank measurements without Crangon crangon were run frequently to calibrate and check the electrodes.

Swimming $\mathrm{MO}_{2}$ was obtained by keeping the respiration chamber horizontal and slowly rotating it $135^{\circ}$ to each side (powered by a small electric motor) so that the sand was moving and Crangon crangon was forced to swim. To obtain $\mathrm{MO}_{2}$ when $C$. crangon was using its abdominal muscle the shrimp was manually hit or irritated on its abdomen by a paddle-bent steel tread inserted into the respiration chamber through a gastight port. The experimentor operated and controlled the 'paddle' so the shrimp could be observed while it continued to jump for as long a period as possible.

\section{RESULTS}

\section{Behaviour in relation to oxygen tensions}

A considerable change in oxygen tension $\left(\mathrm{P}_{\mathrm{w}} \mathrm{O}_{2}\right)$ always evoked a behavioural response in Crangon crangon. Normally, when adapted to a given set of environmental conditions during daytime and allowed to settle after handling, the shrimp buried itself in the sand. When $\mathrm{P}_{\mathrm{w}} \mathrm{O}_{2}$ was rapidly lowered $(15 \mathrm{~min})$ at $20^{\circ} \mathrm{C}$ and $15 \% \mathrm{~S}, \mathrm{C}$. crangon initially raised its front end out of the sand and emerged from the sand at 40 to $50 \%$ $\mathrm{P}_{w} \mathrm{O}_{2}$. At $9^{\circ} \mathrm{C}$, the corresponding $\mathrm{P}_{w} \mathrm{O}_{2}$ was ca $20 \%$. An increase in general activity of the shrimp could be observed when $\mathrm{P}_{\mathrm{w}} \mathrm{O}_{2}$ was further lowered. At a temperature of $20^{\circ} \mathrm{C}$ considerable 'restlessness' was noted after emergence from the substrate, but at a $\mathrm{P}_{\mathrm{w}} \mathrm{O}_{2}$ of $30 \%$ or lower the shrimps became immobile. The 
restlessness must be interpreted as an escape or avoidance reaction and was always in the form of swimming, but not by using the abdominal muscle. If the hypoxia persisted for a longer time, C. crangon emerged from the sand at a higher $\mathrm{P}_{w} \mathrm{O}_{2}$ than if the $\mathrm{P}_{\mathrm{w}} \mathrm{O}_{2}$ was rapidly lowered; at $\mathrm{P}_{\mathrm{w}} \mathrm{O}_{2} 60 \%$ and $20^{\circ} \mathrm{C}$, emergence occurred after $2.5 \mathrm{~h}$.

\section{Oxygen tolerance}

Results of oxygen/salinity/temperature tolerance tests are shown in Fig. 1A \& B, and in Table 1. Shrimp were considered dead when they turned opaque and no response was seen after transfer to oxygenated seawater. Survival was, regardless of salinity, good in
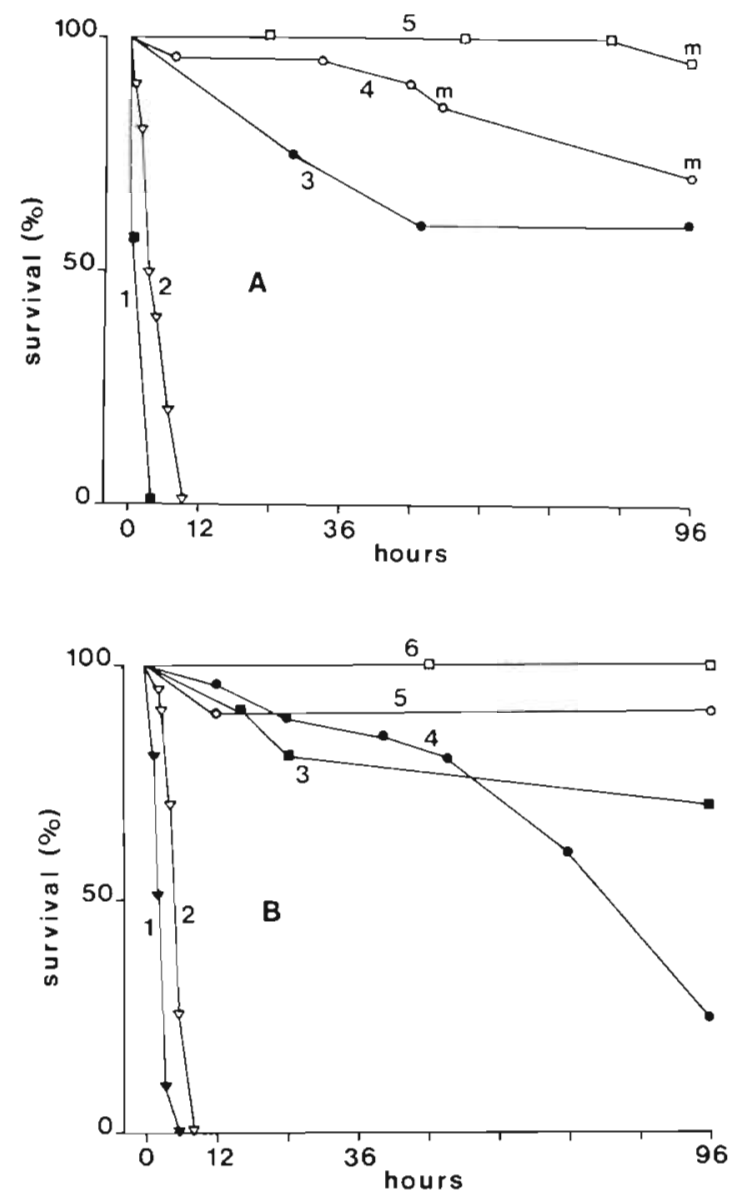

Fig. 1. Crangon crangon. (A) Survival as a function of time upon exposure to different levels of hypoxia; $20 \% \mathrm{~S}, 20^{\circ} \mathrm{C}$. (1) $\mathrm{P}_{\mathrm{w}} \mathrm{O}_{2} \quad 5 \%$ saturation; (2) $\mathrm{P}_{\mathrm{w}} \mathrm{O}_{2} \quad 10 \%$; $\quad$ (3) $\mathrm{P}_{\mathrm{w}} \mathrm{O}_{2} \quad 20 \%$; (4) $\mathrm{P}_{\mathrm{w}} \mathrm{O}_{2} 30 \%$; (5) $\mathrm{P}_{\mathrm{w}} \mathrm{O}_{2} 50 \% ; \mathrm{n}=20$ for each $\mathrm{P}_{\mathrm{w}} \mathrm{O}_{2} ; \mathrm{m}$ : moulting during experiment. (B) Survival as a function of time upon exposure to various levels of salinity and hypoxia; 5 and $10 \% \mathrm{~S}, 20^{\circ} \mathrm{C}$. (1) $5 \% \mathrm{~S}, \mathrm{P}_{w} \mathrm{O}_{2} 10 \%$; (2) $5 \% \mathrm{~S}, \mathrm{P}_{\mathrm{w}} \mathrm{O}_{2}$ $20 \%$; (3) $5 \%$ S, $\mathrm{P}_{w} \mathrm{O}_{2} 30 \%$; (4) $10 \% \mathrm{~S}, \mathrm{P}_{\mathrm{w}} \mathrm{O}_{2} 10 \%$; (5) $10 \%$ $\mathrm{S}, \mathrm{P}_{\mathrm{w}} \mathrm{O}_{2} 20 \%$; (6) $10 \% \mathrm{~S}, \mathrm{P}_{\mathrm{w}} \mathrm{O}_{2} 30 \% ; \mathrm{n}=20$ for each $\mathrm{P}_{\mathrm{w}} \mathrm{O}_{2}$ and salinity combination
Table 1 Crangon crangon. $\mathrm{LT}_{50}(\mathrm{~h})$ as a function of oxygen tensions ( $\mathrm{P}_{\mathrm{w}} \mathrm{O}_{2}$ : saturation) in different salinities at $20^{\circ} \mathrm{C}$

\begin{tabular}{|cccc|}
\hline $\mathrm{P}_{w} \mathrm{O}_{2}, \%$ & \multicolumn{5}{c|}{} \\
& 5 & 10 & 20 \\
\hline 5 & - & - & 1.5 \\
10 & 1.5 & 4.5 & 6 \\
20 & 70 & 150 & 150 \\
30 & 150 & 150 & 150 \\
50 & 150 & 150 & 150 \\
\hline
\end{tabular}

$\mathrm{P}_{\mathrm{w}} \mathrm{O}_{2}$ down to and including $30 \%$ saturation. Some mortality was noted in $\mathrm{P}_{\mathrm{w}} \mathrm{O}_{2} 30 \%$, but mostly only for moulting individuals ( $\mathrm{m}$ in Fig. 1 ). In $20 \% \mathrm{~S}$, the correlation between $\mathrm{P}_{\mathrm{w}} \mathrm{O}_{2}$, time and survival was $\mathrm{r}=0.99$; for survival and $\mathrm{P}_{w} \mathrm{O}_{2}, \mathrm{r}=0.88$; for survival and time, $\mathrm{r}=0.98$.

The response of Crangon crangon to low $\mathrm{P}_{\mathrm{w}} \mathrm{O}_{2}$ is sudden and total: either survival extends over the whole experimental period or death occurs within a few hours. This is seen in the calculations of $\mathrm{LT}_{50}$ (Table 1) showing that this strongly depends on $\mathrm{P}_{\mathrm{w}} \mathrm{O}_{2}$ and salinity. At $5 \% \mathrm{~S}_{1} \mathrm{LT}_{50}$ in $\mathrm{P}_{\mathrm{w}} \mathrm{O}_{2} 10 \%$ was only $1.5 \mathrm{~h}$, increasing to $70 \mathrm{~h}$ in $\mathrm{P}_{\mathrm{w}} \mathrm{O}_{2} 20 \%$ and to more than $150 \mathrm{~h}$ in $\mathrm{P}_{\mathrm{w}} \mathrm{O}_{2} 30 \%$. In 10 and $20 \% \mathrm{~S}, \mathrm{LT}_{50}$ in $\mathrm{P}_{\mathrm{w}} \mathrm{O}_{2}$ $10 \%$ increased to 4.5 and $6 \mathrm{~h}$ respectively. All other combinations tested resulted in $\mathrm{LT}_{50}$ extending the experimental period (up to $150 \mathrm{~h}$ ).

\section{Lactate accumulation in relation to $\mathrm{P}_{\mathrm{w}} \mathrm{O}_{2}$}

Crangon crangon were kept in various oxygen tensions for up to $25 \mathrm{~h}$ (very low $\mathrm{P}_{w} \mathrm{O}_{2}$ until death), and at intervals sampled for circulating lactate. Resulting lactate concentrations (means $\pm \mathrm{SE}$ ) are shown in Fig. 2 . Controls from normoxic shrimp revealed a mean basic lactate concentration of less than $10 \mathrm{mg} 100 \mathrm{ml}^{-1}$ throughout the experiment. Circulating lactate showed generally a low level close to the control values down to a very low $\mathrm{P}_{w} \mathrm{O}_{2}$. An apparent increase in lactate was observed around half-saturation, and at $\mathrm{P}_{\mathrm{w}} \mathrm{O}_{2} 20$ to $30 \%$ the average lactate level was just under $20 \mathrm{mg}$ $100 \mathrm{ml}^{-1}$. An apparent increase in circulating lactate was not evident until $\mathrm{P}_{\mathrm{w}} \mathrm{O}_{2}$ was below $10 \%$ (mean $80 \mathrm{mg} 100 \mathrm{ml}^{-1}$ ) but this is also, as shown above, within the lethal $\mathrm{P}_{\mathrm{w}} \mathrm{O}_{2}$ range. Lactate exhibited a rather pronounced variability due to intraspecific variation (moult stage) and, to some extent, to dilution of some very small haemolymph samples.

When Crangon crangon was kept at $\mathrm{P}_{\mathrm{w}} \mathrm{O}_{2} 30$ to $100 \%$ for $25 \mathrm{~h}$, no increase in circulating lactate was observed. Only at $\mathrm{P}_{\mathrm{w}} \mathrm{O}_{2} \quad 10 \%$ or less did obvious anaerobic metabolism (i.e. accumulation of circulating 


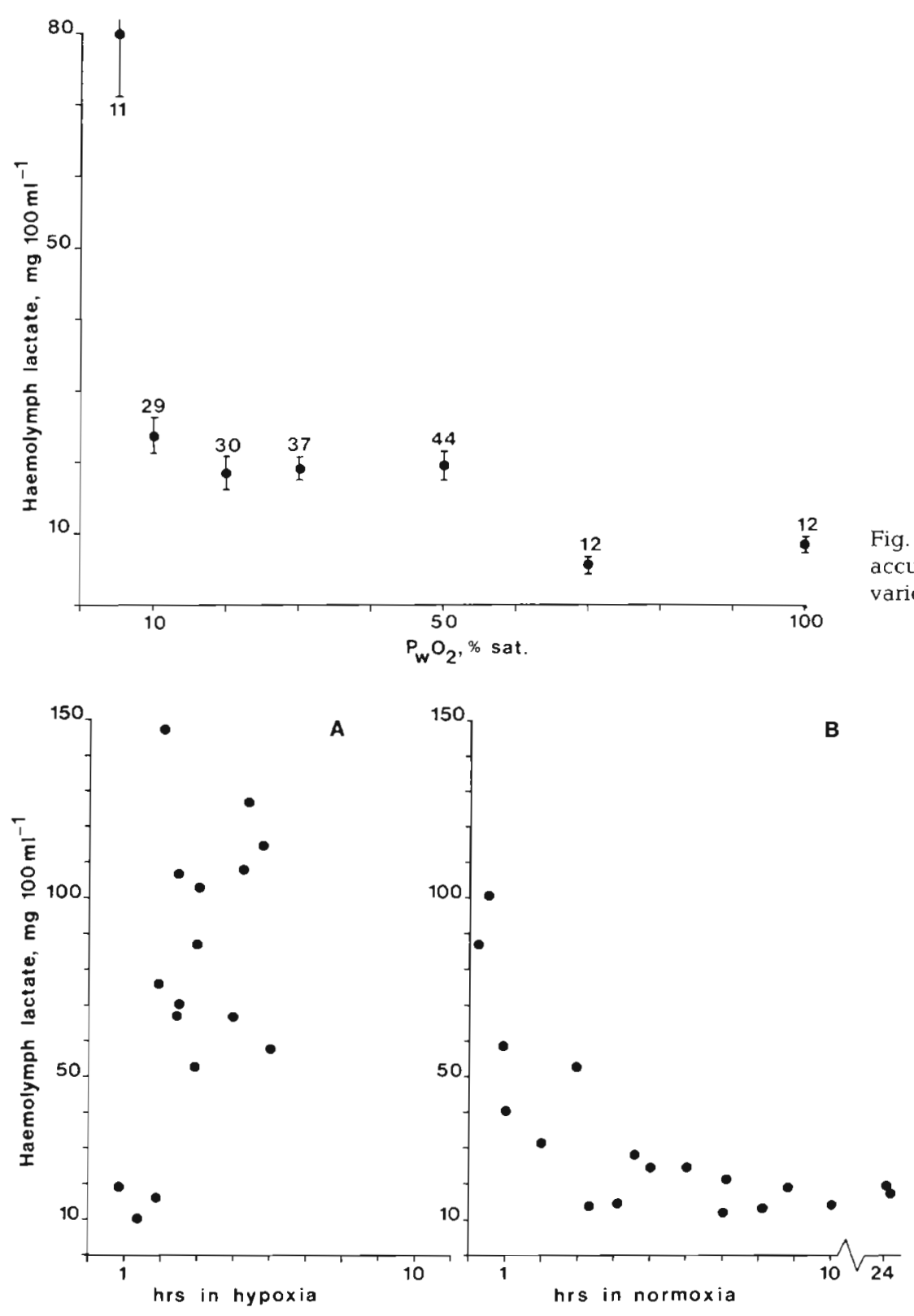

Fig. 3. Crangon crangon. (A) Haemolymph lactate accumulation as a function of time upon exposure to $\mathrm{P}_{\mathrm{w}} \mathrm{O}_{2}$ less than $10 \%$ saturation; $20 \% \mathrm{~S}, 20^{\circ} \mathrm{C}$. (B) Haemolymph lactate re-oxidation as a function of time under normoxic conditions after $2 \mathrm{~h}$ exposure to $\mathrm{P}_{\mathrm{w}} \mathrm{O}_{2}$ less than $10 \%$ saturation; $20 \% \mathrm{~S}, 20^{\circ} \mathrm{C}$ lactate) occur (Fig. 3A). After a low initial value lactate rose sharply to ca $100 \mathrm{mg} 100 \mathrm{ml}^{-1}$ after 3 to $4 \mathrm{~h}$ in an apparently linear increase. C. crangon die at this $\mathrm{P}_{w} \mathrm{O}_{2}$ unless more normoxic conditions occur rapidly. Return to normoxic conditions caused circulating lactate to be reoxidised rapidly (Fig. $3 \mathrm{~B}$ ) returning to approximately normoxic levels after 5 to $6 \mathrm{~h}$.

\section{Lactate accumulation, oxygen consumption and energy demand during swimming}

To investigate whether any increase in circulating lactate occurred during swimming, Crangon crangon was forced to swim for up to $2 \mathrm{~h}$ in different levels of
$\mathrm{P}_{\mathrm{w}} \mathrm{O}_{2}$. Regardless of the $\mathrm{P}_{\mathrm{w}} \mathrm{O}_{2}$, lactate remained close to the range for normoxic shrimp $\left(14.24 \mathrm{mg} 100 \mathrm{ml}^{-1}\right.$; $\mathrm{SE}=2.51 ; n=19)$. At $\mathrm{P}_{\mathrm{w}} \mathrm{O}_{2}$ down to ca $40 \%$ saturation, C. crangon were swimming during at least part of the experiment, while at lower tensions the shrimp were totally inactive and just passively turned around as the experimental chamber rotated. Thus under hypoxia as well as under normoxia no signs of anaerobic metabolism caused by swimming activity were evident in the blood; the shrimp either swam (at higher $\mathrm{P}_{\mathrm{w}} \mathrm{O}_{2}$ ) or remained inactive (lower $\mathrm{P}_{\mathrm{w}} \mathrm{O}_{2}$ ).

When Crangon crangon were forced to swim in the experimental chamber, $\mathrm{MO}_{2}$ rose to varying degrees, from ca $5 \%$ increase of routine $\mathrm{MO}_{2}$ up to $70 \%$ 
increase (mean increase $24.6 \% ; \mathrm{SD} \pm 18.6 \% ; \mathrm{n}=$ 29). Relative changes in $\mathrm{MO}_{2}$ during different types of activity and in different $\mathrm{P}_{\mathrm{w}} \mathrm{O}_{2}$ are shown in Fig. 4. Examples of $\mathrm{MO}_{2}$ and cost of swimming, expressed as C-units, are given in Table 2 . The routine $\mathrm{MO}_{2}$ here is indicative of a specimen well adapted to the experimental chamber: not totally inactive but moving, turning etc. at irregular intervals. In the active phase swimming intensity varies, from almost no swimming at all to swimming during the greater part of the experiment (up to $2 \mathrm{~h}$ ). The shrimp listed in Table 2 were swimming for the greater past of the experiment.

During swimming Crangon crangon uses only part of its energy resources; swimming thus is a normal event in diel activity patterns. There was a tendency towards a higher cost of swimming in smaller specimens (Table 2). As seen from the table, the cost of swimming represents only a small part of the total metabolic cost and varies from a negligible amount to $70 \%$ of the energy used.

A swimming period of up to $2 \mathrm{~h}$ resulted in no lactate accumulation (see above). When swimming stopped,

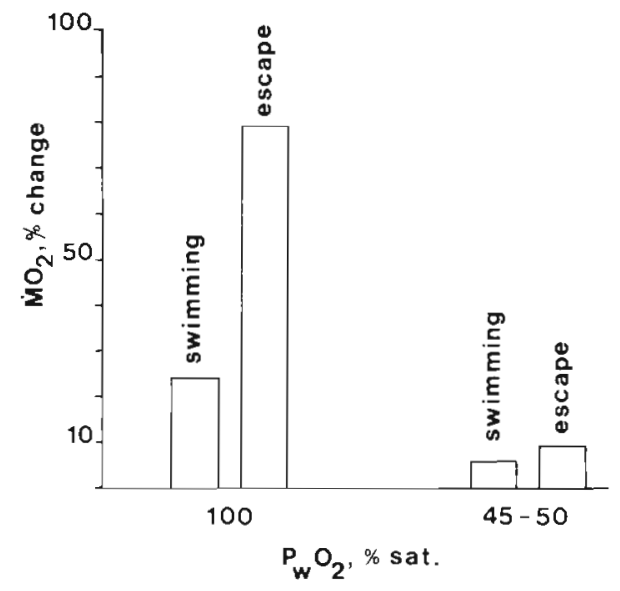

Fig. 4. Crangon crangon. Mean percentage change from routine $\mathrm{MO}_{2}$ during swimming and during escape reactions (maximal activity) at normoxia $\left(\mathrm{P}_{\mathrm{w}} \mathrm{O}_{2} 100 \%\right.$ saturation) and during hypoxia $\left(\mathrm{P}_{\mathrm{w}} \mathrm{O}_{2} 45\right.$ to $50 \%$ saturation); $20 \% \mathrm{~S}, 20^{\circ} \mathrm{C}$
$\mathrm{MO}_{2}$ returned to - or even decreased below - routine levels within a very short time. In some cases Crangon crangon was unable to swim for such long periods and just passively followed the movements of the rotating chamber. Also in these cases $\mathrm{MO}_{2}$ returned to routine rates within minutes.

Under hypoxic conditions $\left(\mathrm{P}_{\mathrm{w}} \mathrm{O}_{2} 40\right.$ to $\left.50 \%\right)$ Crangon crangon was normally more active (p. 126; Hagerman \& Szaniawska unpubl.) and thus the 'routine' - which in this case was an 'active' $-\mathrm{MO}_{2}$ was higher at this $\mathrm{P}_{\mathrm{w}} \mathrm{O}_{2}$ than at normoxia. Consequently, $\mathrm{MO}_{2}$ in shrimp forced to swim was only 10 to $15 \%$ higher than under normoxia (Fig. 4).

\section{Lactate accumulation and oxygen consumption during escape reactions}

Maximal amounts of energy are required in very short periods of time when Crangon crangon use their abdominal muscle which is specialised to perform powerful contractions, so that the shrimp 'jump' away, for instance from predators. Circulating lactate was measured after forcing the shrimps to jump in air or in the experimental chamber. The abdominal muscle fatigued very quickly; after ca 15 contractions the muscle no longer reacted to stimuli, and blood samples were taken. No increase in the circulating lactate was found. The mean level was $10.9 \mathrm{mg} 100 \mathrm{ml}^{-1}(\mathrm{SE}=1.6$; $\mathrm{n}=7$ ), i.e. the same level as for controls at rest.

Upon escape reactions $\mathrm{MO}_{2}$ increased much more than due to swimming. Continuous 'irritation' of Crangon crangon in the experimental chamber gave an increase in routine $\mathrm{MO}_{2}$ of up to $211 \%$ at normoxic $\mathrm{P}_{\mathrm{w}} \mathrm{O}_{2}$. Also here the individual variation was very large (mean $76 \%$; $\mathrm{SD}=62 \% ; \mathrm{n}=13$ ). If $\mathrm{MO}_{2}$ increase was transformed into $\mathrm{C}$-units these outbursts of activity cost up to $0.22 \mathrm{mg} \mathrm{C} \mathrm{g}^{-1} \mathrm{~h}^{-1}$. However, energy expenditure might not be reflected directly in $\mathrm{MO}_{2}$; such violent muscle movements, performed within very short periods of time, could also be based on mechanisms not requiring oxygen. 'Irritation' of the abdominal

Table 2. Crangon crangon. Energy cost of swimming under normoxic conditions; $20 \% \mathrm{~S}, 20^{\circ} \mathrm{C}_{;} \mathrm{MO}_{2}$ expressed as mg $\mathrm{O}_{2} \mathrm{~g}^{-1} \mathrm{~h}^{-1}$ and converted to $\mathrm{mg} \mathrm{C} \mathrm{g}^{-1} \mathrm{~h}^{-1}(\mathrm{RQ}=0.85,1 \mathrm{mg} \mathrm{O}=0.375 \mathrm{mg} \mathrm{C})$

\begin{tabular}{|cccccc|}
\hline $\begin{array}{c}\text { Weight } \\
(\mathrm{w} w \mathrm{wt}, \mathrm{g})\end{array}$ & $\begin{array}{c}\text { Routine } \mathrm{MO}_{2} \\
\left(\mathrm{mg} \mathrm{O} \mathrm{g} \mathrm{g}^{-1} \mathrm{~h}^{-1}\right)\end{array}$ & $\begin{array}{c}\text { Swimming } \mathrm{MO}_{2} \\
\left(\mathrm{mg} \mathrm{C} \mathrm{g} \mathrm{h}^{-1}\right)\end{array}$ & $\begin{array}{c}\text { Cost of swimming } \\
\left(\mathrm{mg} \mathrm{C} \mathrm{g}^{-1} \mathrm{~h}^{-1}\right)\end{array}$ & $\begin{array}{c}\% \text { change in } \mathrm{MO} \mathrm{O}_{2} \text { from } \\
\text { routine to swimming }\end{array}$ \\
\hline 2.0 & 0.24 & 0.076 & 0.091 & 0.015 & 19 \\
0.9 & 0.39 & 0.12 & 0.19 & 0.07 & 58 \\
0.6 & 0.53 & 0.17 & 0.188 & 0.018 & 43 \\
0.45 & 0.502 & 0.16 & 0.23 & 0.07 & 40 \\
0.3 & 0.95 & 0.30 & 0.42 & 0.12 & 38 \\
0.17 & 0.67 & 0.21 & 0.29 & 0.08 & 10 \\
0.09 & 2.45 & 0.78 & 0.86 & 0.08 & \\
\hline
\end{tabular}


muscle continued until the muscle no longer showed any reactions at all to stimuli, normally after 15 to 20 min. $\mathrm{MO}_{2}$ stabilised at the same time; it quickly returned to routine levels without any signs of an oxygen debt.

\section{DISCUSSION}

While it has long been suggested that crustaceans may detect and avoid hypoxic conditions, this has never been well documented. Gammarus oceanicus and Crangon septemspinosa have been shown to respond with an avoidance reaction to anoxic conditions (Cook \& Boyd 1965, Haefner 1971), and the brackish water shrimp Palaemonetes varians increased its swimming activity when $\mathrm{P}_{\mathrm{w}} \mathrm{O}_{2}$ decreased and even tried to jump out of the water (Hagerman \& Uglow 1984). Nephrops norvegicus emerged from its burrow when $\mathrm{P}_{\mathrm{w}} \mathrm{O}_{2}$ reached $25 \%$ (Hagerman \& Uglow 1985). It seems thus reasonable to assume that (1) increasing activity to move away - and where this is not possible and/or the hypoxia severe - (2) inducing a change to an activity level as low as possible in order to conserve available energy, represent general phenomena in crustaceans exposed to varying oxygen tensions.

Oxygen tolerance $\left(\mathrm{LT}_{50}\right)$ in such species is normally high and related to their ability to move. More or less sessile species, e.g. bivalves, show an $\mathrm{LT}_{50}$ considerably higher than crustaceans. Crangon crangon from Kiel Bay exhibited an $\mathrm{LT}_{50}$ to anoxia at $10^{\circ} \mathrm{C}$ of $2 \mathrm{~h}$ (Dries \& Theede 1974), and this corresponds well with our results. Sedgwick (1981) investigated C. crangon from the polluted Thames estuary. Due to the techniques applied his results are difficult to interpret but they show at least that $C$. crangon from the Thames estuary tolerates and reacts to hypoxia at slightly lower levels than found for our C. crangon from the Danish fjords, and from Kiel Bay. Obviously - and also evident from our results - the tolerance to hypoxia is salinity dependent: the higher the salinity $(<20 \%$ S) the lower the $\mathrm{P}_{\mathrm{w}} \mathrm{O}_{2}$ that can be tolerated at comparable temperatures. As C. crangon is isosmotic to the medium at ca $25 \% \mathrm{~S}$ (Hagerman 1971, Spaargaren 1971) it is probable that this shrimp possesses a high tolerance to low $\mathrm{P}_{\mathrm{w}} \mathrm{O}_{2}$ in this salinity.

Blood lactate is always detectable in Crangon crangon. Its values correspond to similar levels in other crustaceans (Bridges \& Brand 1980, Agnew \& Taylor 1985) and is just below $10 \mathrm{mg} \%$. Anaerobic metabolism dominates when oxygen no longer can fuel the basal metabolism in the tissues. In $C$. crangon this point is approached very abruptly $\left(\mathrm{P}_{\mathrm{w}} \mathrm{O}_{2}<10 \%\right)$, indicating a high ability to extract and use available oxygen down to this $\mathrm{P}_{\mathrm{w}} \mathrm{O}_{2}$. Pritchard \& Eddy (1979) and Bridges \& Brand (1980) suggested that lactate accumu- lation and subsequent reoxidation is related to the general ecology of the species, so that burrowing animals, or other animals likely to be subjected to anaerobic conditions, have a faster reoxidation rate. Accumulation of lactate presumably starts at a lower $\mathrm{P}_{\mathrm{w}} \mathrm{O}_{2}$ in species that can maintain their $\mathrm{MO}_{2}$ stable at a lower $\mathrm{P}_{\mathrm{w}} \mathrm{O}_{2}$ than in animals not subjected to fluctuating $\mathrm{P}_{\mathrm{w}} \mathrm{O}_{2}$. In $C$. crangon lactate accumulates only under potentially lethal conditions so that, unless more favourable oxygen conditions occur within 1 to $2 \mathrm{~h}$, the shrimp will die. The lactate accumulation rate found in this investigation is very fast compared to that in Nephrops norvegicus and Corystes cassivelanus (Bridges \& Brand 1980) but this is certainly due to the higher temperature $\left(20\right.$ versus $\left.10^{\circ} \mathrm{C}\right)$.

The time for re-oxidation of the lactate is considerably shorter in the burrowing/digging Carcinus maenas, Corystes cassivelanus and Crangon crangon than in the non-burrowing Galathea strigosa and Homarus gammarus (Bridges \& Brand 1980, Johnson 1985). In C. crangon and other digging forms re-oxidation terminates, despite the above-mentioned difference in experimental temperature, in 5 to 6 hours. According to Hochacka \& Somero (1973) this ability to convert lactate back to glucose is necessary to tolerate high lactate levels; thus species like $C$. crangon which can rapidly accumulate lactate under near-anoxia have the mechanism to use it quickly in gluconeogonesis under normoxia. If reoxidation was slower, then lactate would never be completely reoxidised to normoxic levels, as severe hypoxia under summer conditions might appear at diel intervals (Muus 1967).

The lack of lactate accumulation even during continuous normal swimming shows that aerobic resources are adequate to supply the necessary energy for swimming during normoxia and moderately hypoxic conditions. Even if more severe hypoxia occurs, Crangon crangon responds to this not by turning to an anaerobic metabolism but by ceasing activity.

Available literature suggests that the energetic cost of swimming varies considerably. Increase in $\mathrm{MO}_{2}$ depends, among other things, on activity level, environmental factors, biology of the animal concerned and its body shape. The blue crab Callinectes sapidus increases its $\mathrm{MO}_{2}$ 2.6-fold over routine levels during 'moderate' swimming (Booth et al. 1982). However, this type of blue crab response should be referred to as escape swimming since the normal activity of such a crab is walking. There is further evidence that such blue crab activity is near maximum activity: severe metabolic acidosis occurred with strong lactate accumulation in the haemolymph (Booth et al. 1982). The metabolic cost of walking would thus be considerably less in C. sapidus and perhaps comparable to the cost of swimming in C. crangon, i.e. up to $70 \%$ 
increase in routine $\mathrm{MO}_{2}$. Body shape in relation to medium viscocity presumably reduces the energy requirements for swimming $C$. crangon compared to swimming of blue crab. This is also shown by the low metabolic cost for swimming in a planktonic copepod: less than $1 \%$ of basal metabolism (Vlymen 1970). The 'aerobic scope' for C. crangon should thus be considerably higher than indicated by swimming $\mathrm{MO}_{2}$ in relation to routine $\mathrm{MO}_{2}$. Aerobic metabolic scope of 4 -fold the quiescent rate has been found for, among others, Cancer magister (McMahon et al. 1979). Dall (1986) showed that Penaeus esculentus increased its $\mathrm{MO}_{2}$ by $\sim 130 \%$ when changing its activity level from resting (standard) to swimming. Von Oertzen (1979) found for Palaemon adspersus an increase in $\mathrm{MO}_{2}$ at 15 to $20^{\circ} \mathrm{C}$ of 20 to $60 \%$ when that shrimp exhibited spontaneous' activity, i.e. swimming, and these values are comparable to what we found for $C$. crangon.

Repayment of an oxygen debt will only occur if the hypoxic conditions have been below the $P_{c}$. Consequently, no oxygen debt was noted for Crangon crangon after a period of swimming activity or after exposure to moderate hypoxia as no end products due to anaerobic metabolism had accumulated.

Maximum activity of Crangon crangon and other shrimp, i.e. short outbursts when using the abdominal muscle, cause an increase in $\mathrm{MO}_{2}$ up to $211 \%$, with large individual variations. Onnen \& Zebe (1983) showed that $C$. crangon during such exercises used enormous amounts of energy within a very short time, and this manifests itself only partly in immediate $\mathrm{MO}_{2}$ changes. The abdominal muscle contains a large quantity of phosphagen, and the energy need of the muscle results in a considerable decrease of phosphoarginine until near-depletion. Oxygen supply via haemolymph is not sufficient for these outbursts; instead the shrimp relies on its phosphagen store. When this store is used, fatigue sets in after ca 15 muscle contractions. Increase in $\mathrm{MO}_{2}$ is thus partly a result of a considerable increase in whole-body activity, and partly of processes of reconstituting the phosphagen store as quickly as possible. Circulating lactate did not increase during such exhausting activity, and this corresponds to results of Onnen \& Zebe (1983) who found no remarkable haemolymph lactate increase due to work in C. crangon. However, they noted a considerable lactate increase in tail muscle tissue.

Thus during 'normal' activity there is always enough oxygen available in the medium and in the haemolymph for the metabolic needs of the tissues, while during exhausting exercises the enormous energy requirements of Crangon crangon quickly deplete the stores and fatigue sets in. Under hypoxia during 'normal' activity, fatigue sets in after a period of swimming without $C$. crangon having to turn to anaerobic metabolism. The ecological consequences of this would be a decreased general activity level during long periods of moderate hypoxia and a decreased ability to avoid predators such as fishes and birds. During very severe hypoxic periods $C$. crangon turns to anaerobic metabolism, but at summer temperatures in brackish water this will be lethal within a few hours.

Acknowledgement. This investigation was performed at the Marine Biological Laboratory, Helsingør (Denmark) while one of us (A.Sz.) was in receipt of a fellowship from the Polish State.

\section{LITERATURE CITED}

Agnew, D. J., Taylor, A. C. (1985). The effect of oxygen tension on the physiology and distribution of Echinogrammarus pirloti (Sexton \& Spooner) and E. obtusatus (Dahl) (Crustacea: Amphipoda). J. exp. mar. Biol. Ecol. 87 : 169-190

Booth, C. E., McMahon, B. R., Pinder, A. W. (1982). Oxygen uptake and the potentiating effects of increased hemolymph lactate on oxygen transport during exercise in the blue crab (Callinectes sapidus). J. comp. Physiol. 148: $111-121$

Bridges, C. R., Brand, A. R. (1980). The effect of hypoxia on oxygen consumption and blood lactate levels of some marine crustacea. Comp. Biochem. Physiol. 65 A: 399-409

Cook, R. H., Boyd, C. M. (1965). The avoidance by Gammarus oceanicus Segerstråle (Amphipoda. Crustacea) of anoxic regions. Can. J. Zool. 43: 971-975

Dall, W. (1986). Estimation of routine metabolic rate in a penæid prawn, Penaeus esculentus Haswell. J. exp. mar. Biol. Ecol. 96: 57-74

Dries, R. R., Theede, H. (1974). Sauerstoffmangelresistenz mariner Bodenevertebraten aus der westlichen Ostsee. Mar. Biol. 25: 327-333

Engel, P., Jones, J. B. (1978). Causes and elimination of erratic blanks in the enzymatic metabolic assays involving the use of $\mathrm{NAD}^{+}$in alkaline hydrazine buffers: improved conditions of the assay of L-glutamate, L-lactate and other metabolites. Analyt. Biochem. 88: 475-484

Graham, R. A., Mangum, C. P., Terwilliger, R. C., Terwilliger, N. B. (1983). The effect of organic acids on oxygen binding of hemocyanin from the crab Cancer magister. Comp. Biochem. Physiol. 74 A: 45-50

Haefner, P. A. (1971). Avoidance of anoxic conditions by the sand shrimp, Crangon septemspinosa Say. Chesapeake Science 12: 50-51

Hagerman, L. (1970). Locomotory activity patterns of Crangon vulgaris (Fabr.) (Crustacea, Natantia). Ophelia 8: 255-266

Hagerman, L. (1971). Osmoregulation and sodium balance in Crangon vulgaris (Fabr.) (Crustacea, Natantia) in varying salinities. Ophelia 9: 21-30

Hagerman, L., Uglow, R. F. (1984). The influence of hypoxia on the blood regulation of the brackish water shrimp Palaemonetes varians Leach. J. exp. mar. Biol. Ecol. 76: $157-165$

Hagerman, L., Uglow, R. F. (1985). Effects of hypoxia on the respiratory and circulatory regulation of Nephrops norwegicus. Mar. Biol. 87: 273-278

Hochacka, P. W., Somero, G. N. (1973). Strategies of biochemical adaptation. Saunders, Philadelphia

Johnson, I. T. (1985). Studies on some responses of Carcinus 
maenas (L.) and other brachyurans to hypoxic and aerial exposure. Ph. D. thesis, Univ. of Hull

McMahon, B. R., McDonald, D. G., Wood, C. M. (1979). Ventilation, oxygen uptake and haemolymph oxygen transport, following enforced exhausting activity in the dungeness crab Cancer magister. J. exp. Biol. 80: 271-285

McMahon, B. R., Wilkens, J. L. (1983). Ventilation, perfusion and oxygen uptake. In: Mantel, Linda, H. (ed.) The biology of Crustacea, Vol. 5, Internal anatomy and physiological regulation. Academic Press, New York, p. 289-372

Miljøstyrelsen (1984). Iltsvind og fiskedød i 1981. Omfang og årsager. Ministry of Environmental Protection, Copenhagen

Muus, B. J. (1967). The fauna of Danish estuaries and lagoons. Meddr Danm. Fisk.-og Havunders. N. S. 5: 1-316

von Oertzen, J.-A. (1979). Versuch einer kausalokologischen Leistungsanalyse an brackwasserlebenden Tieren. Thesis, Wilhelm-Pieck-Universität, Rostock, GDR
Onnen, T., Zebe, E. (1983). Energy metabolism in the tail muscles of the shrimp Crangon crangon during work and subsequent recovery. Comp. Biochem. Physiol. $74 \mathrm{~A}$ : $833-838$

Pritchard, A. W., Eddy, S. (1979). Lactate formation in Callianassa californiensis and Upogebia pugettensis (Crustacea: Thalassinidea). Mar. Biol. 50: 248-253

Sedgwick, R. W. (1981). The survival, behaviour and respiratory physiology of Crangon crangon (Fabr.) in the polluted Thames estuary. In: Jones, N. V., Wolff, W. J. (ed.) Feeding and survival strategies of estuarine organisms. Plenum Press, London, p. 123-133

Spaargaren, D. H. (1971). Aspects of the osmotic regulation in the shrimps Crangon crangon and Crangon allmanni. Neth. J. Sea Res. 5: 275-333

Vlymen, N. J. (1970). Energy expenditure of swimming copepods. Limnol. Oceanogr. 15: 348-356

This article was submitted to the editor; it was accepted for printing on September 10, 1986 